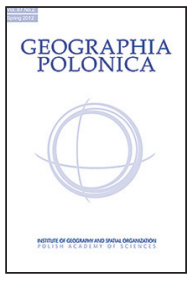

\title{
DEMOGRAPHIC CHANGES IN THE FUNCTIONAL URBAN AREAS IN POLAND, 2000-2010
}

\author{
Przemysław Śleszyński \\ Institute of Geography and Spatial Organization \\ Polish Academy of Sciences \\ e-mail address: psleszyn@twarda.pan.pl
}

Delimitation of Functional Urban Areas (FUAs) ${ }^{1}$ was among the objectives of the ESPON project 1.4.3, Study on Urban Functions, pursued in the period 2005-2007. This objective caused a host of methodological problems due to the difficulty in comparing data required in a detailed procedure and for delimitation criteria. Indirect measures had to substitute work- commuting data, regarded as the best type of data for identifying the extent of the impact of and the connectedness between the suburban and urban core zones, which were unavailable in Poland at the time.

This study draws on said delimitation exercise, but leads to a somewhat different outcome. The difference lies in presenting in full the original idea of delimiting 151 towns and cities with a population of more than 20,000 in 2004. The ESPON project eventually narrowed that sample down to populations of 50,000 or more and added on top of that a higher tier of groupings, includ-

1 The Polish part of the project was headed by Professor Piotr Korcelli, who initiated the delimitation effort. The map with its outcome was first published in: P. Korcelli et al., 2010, Ekspercki Projekt Koncepcji Przestrzennego Zagospodarowania Kraju do roku 2033 [Polish Spatial Development Concept 2033: An Experts' Approach], Studia KPZK PAN, 128, Warszawa, p. 127 (authors: P. Korcelli and P. Śleszyński). ing the Upper Silesian Polycentric Metropolitan Area (Górnoślaski Policentryczny Obszar Metropolitalny, which encompasses Katowice, Rybnik, Bielsko-Biała, Jastrzębie-Zdrój, etc.) and two cross-border urban areas (Görlitz-Zgorzelec and Frankfurt (Oder)).

The delimitation exercise was based on Poland's administrative division into gminas (municipalities), but it also parsed what were known as urban-rural gminas into their urban cores and countryside peripheries, thus bringing the total count of administrative units to 3,057 in 2004. In defining a Functional Urban Area the 20,000plus inhabitants core-size criterion was accompanied by two principles: i.e. spatial-topological continuity and disjointed sets.

These criteria were used to identify 151 areas, whose cores were then delimited. Of this number 134 were individual towns or cities and 17 were aggregates (either urban agglomerations or conurbations). The core boundaries were identified using the density criterion of more than 650 people per $1 \mathrm{~km}^{2}$. The periphery was identified using indirect features related to the urban impact based on statistics. While these features were not relationships by nature, they resulted from certain

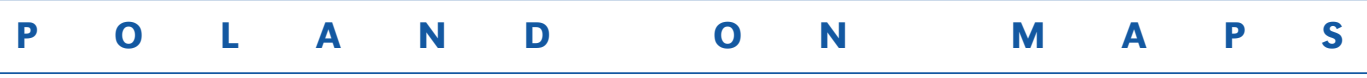


relationships and dependencies existing within the FUA, including (data from 2002 and 2004):

a) employment of permanent residents in the services sector;

b) employment of permanent residents outside agriculture;

c) economic entities to population ratio;

d) local higher-level service economic entities to population ratio;

e) $\mathrm{J}$ and $\mathrm{K}$ section economic entities in the total businesses.

The delimited Functional Urban Areas are shown on the map in Figure 1 and the main details of their cores and peripheries in Table 1 (broken down into categories of cores). The FUAs identified covered an area of $81,700 \mathrm{~km}^{2}$ (including
The map and the accompanying Table 2 present a population change in the FUAs during the period 2000-2010. The Warsaw Area recorded the biggest gain, in both the core and periphery, but elsewhere the picture was mixed. a general pattern was that the lower in the hierarchy a FUA was the greater was its demographic loss, especially in the core. In the category of Metropolitan European Growth Areas (MEGAs), Katowice and Łódź recorded the greatest losses, while other areas typically lost numbers in the core, but gained substantially in the periphery. On the whole, the change in both the absolute numbers and percentages observed suggests a considerable differentiation process going on among Polish urban areas in terms of their trends and sizes during the last decade.

Table 1. Essential characteristics of Functional Urban Areas in Poland (FUAs), 2004.

\begin{tabular}{|c|c|c|c|c|c|c|c|c|c|}
\hline \multirow{2}{*}{$\begin{array}{l}\text { Category } \\
\text { of FUAs }\end{array}$} & \multirow{2}{*}{$\begin{array}{l}\text { Number } \\
\text { of } \\
\text { separate } \\
\text { centres }\end{array}$} & \multicolumn{2}{|c|}{$\begin{array}{c}\text { Number } \\
\text { of administrative } \\
\text { divisions }\end{array}$} & \multicolumn{2}{|c|}{$\begin{array}{l}\text { Area } \\
\left(\mathrm{km}^{2}\right)\end{array}$} & \multicolumn{2}{|c|}{$\begin{array}{l}\text { Population } \\
\text { (thousand) }\end{array}$} & \multicolumn{2}{|c|}{$\begin{array}{l}\text { Population density } \\
\text { (inhabitants } \mathrm{km}^{2} \text { ) }\end{array}$} \\
\hline & & total & core & total & core (\%) & total & core $(\%)$ & core & $\begin{array}{c}\text { external } \\
\text { zone }\end{array}$ \\
\hline Capital state & 1 & 75 & 20 & 4,548 & 20.9 & 2,785 & 77.9 & 2,282 & 171 \\
\hline Other MEGAs & 7 & 240 & 48 & 19,221 & 20.0 & 8,812 & 76.4 & 1,753 & 135 \\
\hline Other regional centres & 14 & 170 & 22 & 14,955 & 12.5 & 4,782 & 68.4 & 1,751 & 115 \\
\hline $\begin{array}{l}\text { Other subregional } \\
\text { centres }\end{array}$ & 55 & 269 & 61 & 23,213 & 12.8 & 5,692 & 70.8 & 1,352 & 82 \\
\hline Local centres A & 30 & 71 & 30 & 8,276 & 9.6 & 1,464 & 71.8 & 1,321 & 55 \\
\hline Local centres B & 44 & 98 & 44 & 11,496 & 7.6 & 1,525 & 68.7 & 1,198 & 45 \\
\hline Total & 151 & 923 & 225 & 81,709 & 13.8 & 25,060 & 73.0 & 1,618 & 96 \\
\hline
\end{tabular}

* Categories of FUAs: capital state - Warsaw Metropolitan Area; other MEGAs - Cracow, Gdańsk/Tri-city, Katowice, Łódź, Poznań, Szczecin, Wrocław; other regional centres - other capital of voivodeships and Bielsko-Biała, Częstochowa, Radom and Rybnik; other subregional centres - cities with poviat status and other cities above population of 50,000; local centres A - other towns above population of 30,000; local centres B - other towns (above population of 20,000).

$11,300 \mathrm{~km}^{2}$ of cores, i.e. $13.8 \%$ ) and had a population of 25.1 million (including 18.3 million or $73.0 \%$ in the cores). This accounted for $26.1 \%$ of the area and $65.7 \%$ of the population of Poland. The FUAs comparised 1,148 administrative units (including urban or rural gminas and the urban and rural portions of urban-rural municipalities). Of this number 222 towns and cities constituted the cores and 166 were included in the external areas.

The most populous of the FUAs included: Katowice (total population of 3,028 thousand), Warsaw (2,785 thousand), Cracow (1,236 thousand), Łódź (1,165 thousand) and Gdańsk (993 thousand). Looking at large categories, four FUAs exceeded 1 million inhabitants, 12 had 300,000 to 1 million, 31 had 100,000-300,000 and 104 had less than 100,000.
Table 2. Population changes in Functional Urban Areas in Poland (FUAs), 2000-2010.

\begin{tabular}{|c|c|c|c|c|c|c|}
\hline \multirow{2}{*}{$\begin{array}{l}\text { Category } \\
\text { of FUAs } \\
\text { (see Tab. 1) }\end{array}$} & \multicolumn{2}{|c|}{ Total } & \multicolumn{2}{|c|}{ Core } & \multicolumn{2}{|c|}{ External zone } \\
\hline & $\begin{array}{c}\text { in thou- } \\
\text { sand }\end{array}$ & $\%$ & $\begin{array}{l}\text { in thou- } \\
\text { sand }\end{array}$ & $\%$ & $\begin{array}{l}\text { in } \\
\text { thou- } \\
\text { sand }\end{array}$ & $\%$ \\
\hline Capital state & 263.3 & 10.0 & 174.4 & 8.5 & 88.9 & 15.5 \\
\hline Other MEGAs & -81.2 & -0.9 & -243.8 & -3.6 & 162.6 & 8.0 \\
\hline $\begin{array}{l}\text { Other regional } \\
\text { centres }\end{array}$ & 6.5 & 0.1 & -71.1 & -2.1 & 77.7 & 5.2 \\
\hline $\begin{array}{l}\text { Other } \\
\text { subregional } \\
\text { centres }\end{array}$ & -160.9 & -2.8 & -208.0 & -5.0 & 47.1 & 2.8 \\
\hline Local centres A & -43.4 & -2.9 & -61.1 & -5.6 & 17.7 & 4.3 \\
\hline Local centres B & -47.9 & -3.1 & -53.1 & -4.9 & 5.2 & 1.1 \\
\hline Total & -63.5 & -0.3 & -462.7 & -2.5 & 399.2 & 6.0 \\
\hline
\end{tabular}




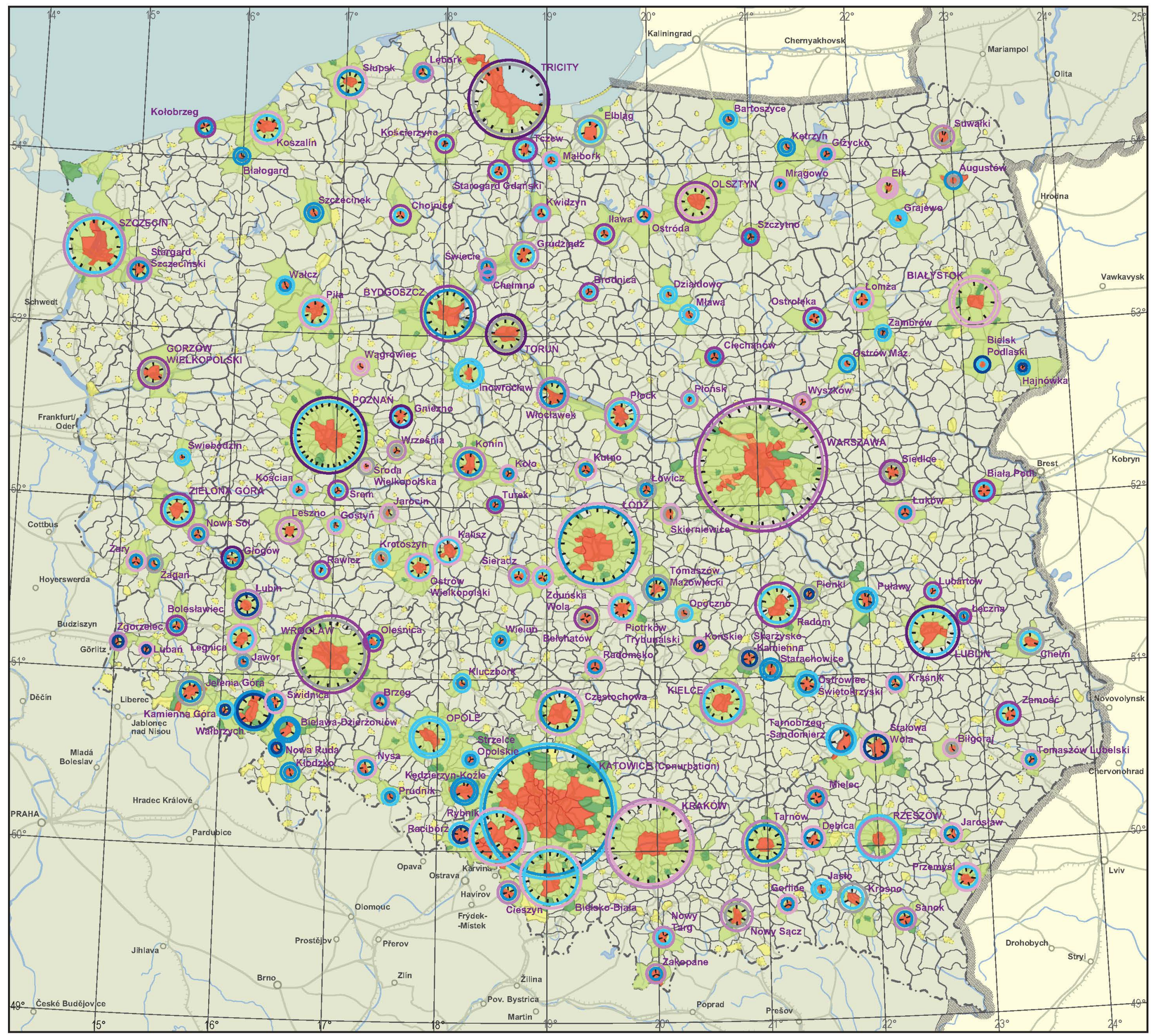

DEMOGRAPHIC CHANGES

IN THE FUNCTIONAL URBAN AREAS IN POLAND, 2000-2010

Przemysław Śleszyński

Scale 1:3,000,000

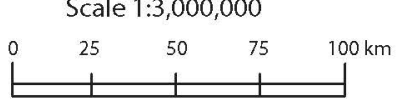

Cores

urban
rura
External zones

urban

rural other cities in their administrative borders

Number of population and their changes, 2000-2010
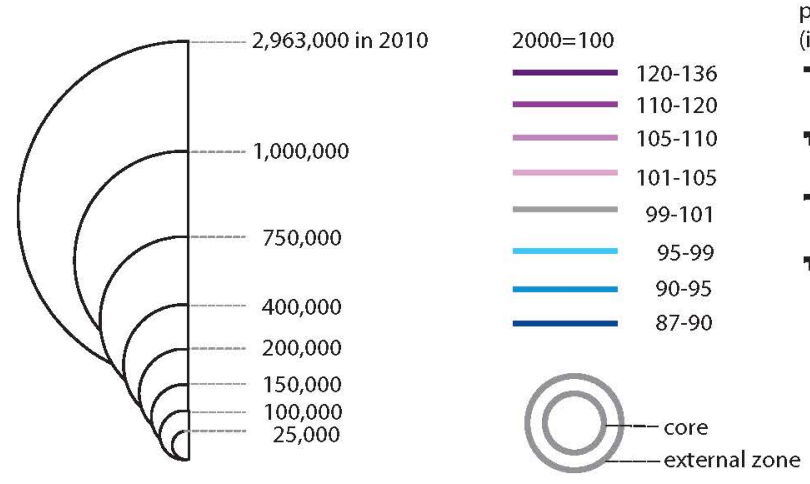

changes in the core part of the tot (in percentage points, pp)

1 to5 pp

入 -1 to $1 \mathrm{pp}$

-1 to $-5 p p$

7 - -5 to $-12 \mathrm{pp}$

-...-. countries

—_ voivodeships

poviats (counties)

- gminas

towns in gminas (communes) with urban-rural administrative status

TRICITY Gdańsk, Gdynia, Sopot

KATOWICE (conurbation) Cities with poviat rights: Bytom, Chorzów, Dabrowa Gómicza, Gliwice, Slaskie, Sosnowiec, Swits Chełmek, Chrzanów, Czeladż, Czerwionka-Leszczyny, Knurów, Łaziska Górne Mikołów, Pyskowice, Radzionków, Tarnowskie Góry, Wojkowice

TrAiPZ

Sleszyński P., 2013. Demographic changes in the functional urban areas in Poland, 2000-2010. INSTITUTE OF GEOGRAPHY AND SPATIAL ORGANIZATIO http://dx.doi.org./10.7163/GPol.2013.16 